\title{
Evaluation of the myocardial performance index in prediabetic patients
}

\section{Prediyabetik hastalarda \\ miyokard \\ indeksinin değerlendirilmesi}

performans

\author{
Isa Ardahanli1', Yasar Turan ${ }^{1}$, Elif Turan², Ahmet Aktas ${ }^{3}$
}

\author{
${ }^{1}$ Department of Cardiology, Bilecik State Hospital, Bilecik, Turkey \\ 2 Department of Endocrinology and Metabolism, Faculty of Medicine, Bozok University, Yozgat, Turkey \\ ${ }^{3}$ Department of Internal Medicine, Faculty of Medicine, Cumhuriyet University, Sivas, Turkey \\ Corresponding author: Isa Ardahanli, MD, Department of Cardiology, Bilecik State Hospital, Bilecik, Turkey \\ E-mail: isaardahanli@gmail.com \\ Received/Accepted: June 10, 2019 /June 27, 2019 \\ Conflict of interest: There is not a conflict of interest.
}

\section{SUMMARY}

Objective: Prediabetes; is the first stage of diabetes. It is a high-risk status for the development of diabetes mellitus type 2, which is an important public health problem. Myocardial performance index (MPI) is a noninvasive method that can be measured by echocardiography showing left ventricular (LV) systolic and diastolic functions. In this study, we aimed to investigate the relationship between prediabetes and MPI.

Method: Fifty-three consecutive patients without chronic illness who were diagnosed with prediabetes and 48 otherwise healthy subjects were enrolled in the study. Fasting blood glucose and HbAlc levels were measured from venous blood samples. MPI values were calculated by tissue Doppler imaging technique for all participants.

Results: In the prediabetic group, the mean fasting blood glucose level was $115 \pm 4 \mathrm{mg} / \mathrm{dL}$, whereas in the control group it was $90 \pm 5 \mathrm{mg} / \mathrm{dL}$. As expected, $\mathrm{HbA1c}$ was statistically significantly higher in the patient group. (\% 5,7 $\pm 0,3$ vs $\% 5,1 \pm 0,3$, respectively). The MPI values in the patient group were higher than the control group and this difference was statistically significant $(0.74 \pm 0.12$ vs. $0.64 \pm 0.09 ; \mathrm{p}<0,001)$. There were no statistically significant differences between the groups in terms of age, gender, and body mass index.

Conclusions: In prediabetic patients, MPI was higher than the control group, which may be related to impaired LV systolic and diastolic functions.

Keywords: Prediabetes, myocardial performance index, tissue doppler imaging

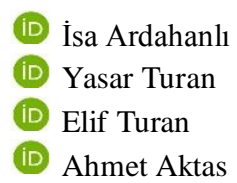

ORCID IDs of the authors: İ.A. 0000-0002-9309-803X Y.T. 0000-0002-2796-899X E.T. 0000-0002-8228-6932 A.A. $0000-0001-9464-0700$ 
Amaç: Prediyabet; diyabetin ilk aşamasıdır. Önemli bir halk sağlığı sorunu olan Tip 2 diabetes mellitus gelişimi için yüksek riskli bir durumdur. Miyokard performans indeksi (MPI) sol ventrikül (LV) sistolik ve diyastolik fonksiyonları gösteren, ekokardiyografi ile ölçülebilen non invaziv bir yöntemdir. Bu çalışmada prediyabet ile MPI arasındaki ilişkiyi araştırmayı amaçladık.

Yöntem: Prediyabet tanısı konulmuş, kronik hastalığı olmayan 50 ardışık hasta ve 48 sağlıklı kiși çalışmaya dahil edildi. Açlık kan glukozu ve HbAlc düzeyleri venöz kan örneklerinden ölçüldü. MPİ değerleri tüm katılımcılar için doku doppler görüntüleme tekniği ile hesaplandı.

Bulgular: Prediyabetik grupta ortalama açlık kan glukoz düzeyi $115 \pm 4 \mathrm{mg} / \mathrm{dL}$ iken, kontrol grubunda $90 \pm 5 \mathrm{mg}$ / dL idi. Beklendiği gibi, HbAlc hasta grubunda istatistiksel olarak anlamlı derecede yüksekti. (Sırasıyla \% 5,7 \pm $0,3 \mathrm{ve} \% 5,1 \pm 0,3)$. Hasta grubunun MPİ değerleri kontrol grubuna göre yüksekti ve bu fark istatistiksel olarak anlamlıydı (sırasıyla $0.74 \pm 0.12$ vs. $0.64 \pm 0.09 ; \mathrm{p}<0.001$ ). Gruplar arasında yaş, cinsiyet ve vücut kitle indeksi açısından istatistiksel olarak anlamlı fark yoktu.

Sonuç: Prediyabetik hastalarda, MPİ kontrol grubundan daha yüksekti, bu durum bozulmuş LV sistolik ve diyastolik fonksiyonlarla ilişkili olabilir.

Anahtar sözcükler: Prediyabet, miyokardiyal performans indeksi, doku doppler görüntüleme

\section{INTRODUCTION}

Cardiovascular diseases (CVD) remain the leading cause of death worldwide. Therefore; prevention of CVD has become public health precedence. Hyperglycemia is a well-established risk factor for cardiovascular disease ${ }^{1-3}$. It is expressed in the National Cholesterol Education Program - Adult Treatment Panel III ( NCEP ATP III) guideline, 'diabetes is considered as the risk equivalent for cardiovascular diseases.' One in every 11 adults in the world is diagnosed with diabetes mellitus (DM), and more than $90 \%$ of these patients form type 2 diabetes ${ }^{4}$. Due to the aging of the population and the widespread obesity, the prevalence is steadily increasing 5 . DM is a metabolic and chronic disorder characterized by hyperglycemia. Type $1 \mathrm{DM}$ is related to the absolute deficiency of insulin, and Type $2 \mathrm{DM}$ is the type that is characterized by a partial deficiency or insulin resistance in the peripheral tissues ${ }^{6}$.

DM has long-term microvascular and macrovascular complications, both of which affect the cardiovascular system ${ }^{7}$. Myocardial injury in DM occurs due to coronary macrovascular and microvascular diseases, autonomic dysfunction, and diabetic cardiomyopathy. These physiopathological mechanisms often coexist and potentiate the effects of each other. Prediabetes is defined as the first stage of diabetes mellitus. According to the definition of American Diabetes Association (ADA), prediabetes is the coexistence of impaired fasting glucose (IFG), impaired glucose tolerance (IGT), or both, and $\mathrm{HbA} 1 \mathrm{c}$ is $5.7 \%$ to $6.4 \%{ }^{6}$. Studies have shown that DM develops in approximately $25-30 \%$ of patients with prediabetes within 3 to 5 years ${ }^{8}$.

Although DM is a well-known risk factor for CVD, there is also vascular damage in the prediabetic period. Previously, several studies have established a relationship between prediabetes and $\operatorname{CVD}^{9,10,11}$.

Myocardial performance index (MPI), is a nongeometrical noninvasive assessment of global left ventricular function, including components from both systole and diastole ${ }^{12}$. The MPI provides prognostic information about morbidity and mortality in patients with ischemic heart disease and cardiomyopathy (13). It has also been shown that MPI can be used to assess the cardiac functions in many autoimmune diseases with cardiac involvement and cardiac amyloidosis ${ }^{12-15}$. Also, in a study conducted in 2007, MPI was found to predict cardiovascular outcomes in patients with $\mathrm{DM}^{16}$.

Prevention of complications caused by any disease is directly related to early detection of the disease and early detection of damage to the organs. In this study, we aimed to evaluate the MPI in prediabetic patients and to test the usability and strength of MPI as a screening test. It can also show whether MPI is different from normal individuals in prediabetic patients.

\section{MATERIAL AND METHODS}

\section{Inclusion and exclusion criteria}

In this prospective study, fifty-three consecutive prediabetic patients (prediabetic group) and 48 normal individuals (control group) who applied to the Department of Cardiology and Endocrinology from December 2015 to August 2016 were compared and analyzed. All subjects had no history of cardiovascular disease, and they were normotensive. Patients with a fasting blood glucose of $100-125 \mathrm{mg} / \mathrm{dL}$ were identified as IFG. Patients with a blood glucose of 140-199 mg / dL measured 2 hours after an oral glucose tolerance test (OGTT) were considered IGT. 
Patients with IFG, IGT, or both (IFG + IGT) constituted the prediabetic patient group. Fasting blood glucose $<100 \mathrm{mg} / \mathrm{dL}$ and 2nd-hour glucose values $<140$ were taken as a control group. This study approved by the Research and Ethics Committee of Bozok University. Written informed consent was received from all participants. This study was performed by the standards of the Declaration of Helsinki.

The following patients were excluded from the study:

- Patient with known coronary artery disease,

- Congestive heart failure,

- Cardiac arrhythmia,

- Hypertrophic cardiomyopathy,

- Pericardial disease,

- Chronic pulmonary disease,

- Moderate or severe heart valvular disease,

- Patients followed for malignancy,

- Patients with active infection or infection during the last two weeks,

- Pregnant women,

- Type 1 or 2 Diabetes Mellitus

- Patients with chronic renal disease (glomerular filtration rate of $<60 \mathrm{ml} / \mathrm{min}$ ).

- Thyroid gland dysfunction

\section{General assessment and measurements}

A complete medical history and physical examination were performed in all the cases studied. Individuals weighed with lightweight clothes. The body weight, waist circumference, and height were measured. Body mass index (BMI) was calculated using the following formula: BMI=weight $(\mathrm{kg}) /$ height $\left(\mathrm{m}^{2}\right)$. In terms of abdominal obesity, the smallest waist circumference between the lowest costa and the Spina iliaca anterior superior; was measured by measuring the transverse mass parallel to the side of the umbilicus. The waist circumference of $\geq$ $102 \mathrm{~cm}$ for men and $\geq 88$ for women was accepted as increased waist circumference ${ }^{17}$.

\section{Echocardiographic examination}

Echocardiographic measurements were performed in the left lateral decubitus position according to the recommendations of the American Echocardiography Society ${ }^{18}$. Echocardiographic TDI program was used to perform tissue Doppler imaging. Tissue Doppler sample volume was placed on the septal and lateral sides of the mitral annulus in apical four-chamber view. Respectively, early diastolic peak (Em), late diastolic peak (Am), and systolic flow peak velocities $(\mathrm{Sm})$ were measured in the annulus of the septal and lateral walls. Isovolumetric contraction time (IVCT), isovolumetric relaxation time (IVRT), and ejection times (ET) were measured. MPI was calculated by the following formula; IVCT+ IVRT/ ET. Discrimination between systole and diastole was performed using the patients' echocardiographic records. The measurements were made by the same cardiologist who did not have patient data.

To decide the interobserver variability, 15 of the investigation patients were chosen for echocardiographic assessment, and MPI estimations were rehashed after ten days. The reproducibility of the measurements was statistically significant (intraclass correlation coefficient $0,831, \mathrm{p}<0,001$ )

\section{Laboratory measurements}

Antecubital vein blood samples were taken following 12 hours of fasting. Complete blood counts were analyzed within 45 minutes following blood sample collection. The venous blood samples taken for biochemical tests were centrifuged at $3000 \mathrm{rpm}$ and held at $-80^{\circ} \mathrm{C}$ until analysis. HbA1c was measured with Abbott CI8000 . Analyzes were performed by a laboratory technician who did not have patient data. The following parameters were measured during the laboratory analysis: fasting blood glucose level, $\mathrm{HbA1c}$, creatinine, sodium, potassium, blood urea nitrogen, aspartate transaminase, alanine transaminase, albumin, total protein, thyroidstimulating hormone, total cholesterol, lowdensity lipoprotein, very low- density lipoprotein, high-density lipoprotein, triglycerides and $\mathrm{C}$ reactive protein (CRP).

\section{Statistical analysis}

For the analysis of the data, the package program SPSS 18.0 (Statistical Package for Social Sciences - SPSS, Inc., Chicago, Illinois, USA) was used. Categorical variables were expressed as a percentage. Continuous variables were reported as mean, standard deviation (mean $\pm \mathrm{SD}$ ). The onesample Kolmogorov-Smirnov test was used to evaluate whether the variables showed a normal distribution. The linear relationship between the parameters with normal distribution was assessed using the Pearson correlation test. Spearman correlation test was used among those who did not have a normal distribution. Mann-Whitney U test was used to compare the differences between the groups in continuous variables. The results were considered significant at $\mathrm{p}<0,05$. 


\section{RESULTS}

Age, height, body weight, BMI, gender, and waist circumference were statistically similar in both groups (Table 1). The number of patients with hypertension in the prediabetes group $(\mathrm{n}=10)$ was higher than the control group $(n=7)$, but not statistically significant $(p=0,380)$. The number of obese patients in the prediabetic group $(n=36 / 53)$ was similar to that in the control group ( $\mathrm{n}=33 / 48)$ $(\mathrm{p}=0,902)$.

Mean LVEF (\%) was $63 \pm 2$ in all subjects included in the study. LVEDD, LVESD, LVEF, IVSd, PWD, aortic diameter, and pulmonary artery systolic pressure were statistically similar in both groups ( $>0.05$ ) (Table 2). The rate of mitral E / A wave, which is a diastolic dysfunction indicator, was significantly lower in the prediabetics than in the control group. ( $0,8 \pm 0,3$ vs. $1,4 \pm 0,5$, respectively; $p<0.001)$. The ratio of tissue Doppler lateral Em / Am waves, as important findings of diastolic dysfunction, were in the control group $(1,4 \pm 0,3$ vs. $1 \pm 0,3$, respectively; $p$ values $<0,001)$. IVCT was similar between both groups $(\mathrm{p}=0.885)$. IVRT was longer in the prediabetic group than the control group and was statistically significant $(91 \pm 15$ vs. $83 \pm 16$, respectively; $p=0,019$ ). The ET was significantly longer in the control group than the prediabetic group $(264 \pm 28$ vs. $241 \pm 28$; $\mathrm{p}<0.001)$. MPI values were increased in the prediabetic group than the control group $(0,74 \pm 0,12$ vs $0,64 \pm 0,09$, respectively; $\mathrm{p}<0.001)$. (Table 3).

As expected, the values of fasting blood glucose and $\mathrm{HbAlc}$ were significantly higher in the prediabetes group than the control group $(115 \pm 4$ vs. $90 \pm 5 ; \mathrm{p}<0,001$ and $5,7 \pm 0,3$ vs. $5,1 \pm 0,3$; $\mathrm{p}<0,001$, respectively). The CRP levels in the prediabetic group were higher than that in the control group, and it was statistically significant $(p=0,002)$. The laboratory values in each group are shown in Table 4.

\begin{tabular}{|l|c|c|c|}
\hline & $\begin{array}{c}\text { Control } \\
(\mathbf{n = 4 8})\end{array}$ & $\begin{array}{c}\text { Prediabetes } \\
(\mathbf{n = 5 3 )}\end{array}$ & p-value \\
\hline Age (years) & $47 \pm 11$ & $51 \pm 9$ & 0,132 \\
\hline Male/Female (\%) & $46 / 54$ & $38 / 62$ & 0,410 \\
\hline Height (m) & $1,66 \pm 0,08$ & $1,63 \pm 0,07$ & 0,114 \\
\hline Weight (kg) & $86 \pm 12$ & $86 \pm 15$ & 0,996 \\
\hline Waist circumference (cm) & $100 \pm 12$ & $100 \pm 12$ & 0,364 \\
\hline BMI (kg/m) & $28,9 \pm 5,0$ & $29,0 \pm 3,7$ & 0,312 \\
\hline $\begin{array}{c}\text { Family History of CAD } \\
\text { (present/absent) (\%) }\end{array}$ & $4 / 44(8 / 92)$ & $2 / 51(4 / 96)$ & 0,333 \\
\hline $\begin{array}{c}\text { Smoking Non-smoker (\%) } \\
\text { Active smoker (\%) }\end{array}$ & $36(75)$ & $44(83)$ & 0,321 \\
\hline
\end{tabular}

significantly lower in the prediabetic group than

Table 1: Demographic data

CAD: Coronary artery disease; BMI: Body mass index

Table 2: Echocardiographic measurements

\begin{tabular}{|l|l|l|l|}
\hline & $\begin{array}{l}\text { Control } \\
(\mathbf{n = 4 8})\end{array}$ & $\begin{array}{l}\text { Prediabetes } \\
(\mathbf{n = 5 3})\end{array}$ & p -value \\
\hline Aortic diameter $(\mathbf{c m})$ & $3,3 \pm 0,3$ & $3,4 \pm 0,4$ & 0,538 \\
\hline Left atrium $(\mathbf{c m})$ & $3,2 \pm 0,2$ & $3,4 \pm 0,2$ & 0,012 \\
\hline LVEDD $(\mathbf{c m})$ & $4,6 \pm 0,3$ & $4,6 \pm 0,3$ & 0,889 \\
\hline EF $(\%)$ & $63 \pm 2$ & $62 \pm 2$ & 0,195 \\
\hline IVS thickness $(\mathbf{c m})$ & $0,9 \pm 0,1$ & $0,9 \pm 0,1$ & 0,363 \\
\hline PW thickness $(\mathbf{c m})$ & $0,9 \pm 0,0$ & $0,9 \pm 0,1$ & 0,633 \\
\hline PASB $(\mathbf{m m H g})$ & $20 \pm 4$ & $20 \pm 4$ & 0,862 \\
\hline E/A ratio & $1,4 \pm 0,5$ & $0,8 \pm 0,3$ & $<\mathbf{0 , 0 0 1}$ \\
\hline
\end{tabular}

LVEDD: left ventricular end-diastolic diameter; IVS: interventricular septum; PW: posterior wall 
Table 3: Myocardial Performance Index and Tissue Doppler measurements

\begin{tabular}{|l|c|c|c|}
\hline & $\begin{array}{c}\text { Control } \\
(\mathbf{n = 4 8})\end{array}$ & $\begin{array}{c}\text { Prediabetes } \\
(\mathbf{n = 5 3})\end{array}$ & p-value \\
\hline Lateral TDI Em $(\mathbf{c m} / \mathbf{s})$ & $14 \pm 2$ & $12 \pm 3$ & $<\mathbf{0 , 0 0 1}$ \\
\hline Lateral TDI Am $(\mathbf{c m} / \mathbf{s})$ & $10 \pm 2$ & $12 \pm 2$ & 0,539 \\
\hline Lateral TDI Sm $(\mathbf{c m} / \mathbf{s})$ & $10 \pm 1$ & $9 \pm 2$ & $<\mathbf{0 , 0 0 1}$ \\
\hline Lateral Em/Am & $1,4 \pm 0,3$ & $1 \pm 0,3$ & $<\mathbf{0 , 0 0 1}$ \\
\hline Septal TDI Em $(\mathbf{c m} / \mathbf{s})$ & $11 \pm 2$ & $8 \pm 2$ & $<\mathbf{0 , 0 0 1}$ \\
\hline Septal TDI Am $(\mathbf{c m} / \mathbf{s})$ & $8 \pm 1$ & $9 \pm 1$ & 0,810 \\
\hline Septal TDI Sm $(\mathbf{c m} / \mathbf{s})$ & $7 \pm 1$ & $7 \pm 1$ & $<\mathbf{0 , 0 0 1}$ \\
\hline Septal Em/Am & $1,3 \pm 0,3$ & $0.89 \pm 0.3$ & 0,885 \\
\hline IVCT $(\mathbf{m s n})$ & $85 \pm 13$ & $85 \pm 14$ & 0,019 \\
\hline IVRT (msn) & $83 \pm 16$ & $91 \pm 15$ & $<\mathbf{0 , 0 0 1}$ \\
\hline ET $(\mathbf{m s n})$ & $264 \pm 28$ & $241 \pm 28$ & $<\mathbf{0 , 0 0 1}$ \\
\hline MPI & $0,64 \pm 0,09$ & $0,74 \pm 0,12$ & \\
\hline
\end{tabular}

TDI: tissue Doppler imaging; Em: early diastolic velocity; Am: late diastolic velocity; Sm: peak systolic velocity; IVCT:

isovolumetric contraction time; IVRT: isovolumetric relaxation time; ET: ejection time; MPI: Myocardial performance index

Table 4: Laboratory values

\begin{tabular}{|l|c|c|c|}
\hline & $\begin{array}{c}\text { Control } \\
(\mathbf{n = 4 8})\end{array}$ & $\begin{array}{c}\text { Prediabetes } \\
(\mathbf{n = 5 3})\end{array}$ & p-value \\
\hline WBC (10 $/ \mathbf{\mu l})$ & $7685 \pm 2415$ & $8264 \pm 2860$ & 0,277 \\
\hline Neutrophil (10 $/ \mathbf{\mu l})$ & $4,43 \pm 2,02$ & $4,64 \pm 1,96$ & 0,589 \\
\hline Lymphocyte (10 $/ \mathbf{\mu l})$ & $2,54 \pm 0,66$ & $2,54 \pm 1,06$ & 0,972 \\
\hline Hemoglobin $(\mathbf{g r} / \mathbf{d L})$ & $14,3 \pm 1,3$ & $13,8 \pm 1,5$ & 0,107 \\
\hline Fasting blood glucose (mg/ dL) & $90 \pm 5$ & $115 \pm 4$ & $<\mathbf{0 , 0 0 1}$ \\
\hline Creatinin (mg/dL) & $0,79 \pm 0,15$ & $0,76 \pm 0,12$ & 0,178 \\
\hline CRP (mg/L) & $1,9 \pm 2,8$ & $4,1 \pm 3,9$ & 0,002 \\
\hline Total cholesterol (mg/dL) & $196 \pm 30$ & $199 \pm 36$ & 0,721 \\
\hline Triglycerides (mg/dL) & $133 \pm 44$ & $179 \pm 99$ & 0,005 \\
\hline HDL (mg/dL) & $47 \pm 7$ & $44 \pm 7$ & 0,039 \\
\hline LDL (mg/dL) & $118 \pm 28$ & $119 \pm 30$ & 0,848 \\
\hline HbA1c (\%) & $5,1 \pm 0,3$ & $5,7 \pm 0,3$ & $<\mathbf{0 , 0 0 1}$ \\
\hline
\end{tabular}

WBC:White blood cells,CRP: C-reactive protein 


\section{DISCUSSION}

In our study, MPI and its constituent IVRT and ET parameters were measured as prolonged in the prediabetic group according to the control group. Prediabetes was strongly correlated with MPI. The most significant factor in the high MPI was seen as the higher incidence of IVRT in the prediabetic group compared to the control group. IVRT is a very active period and is energy dependent. With the cause of ischemia, enough ATP cannot be produced in the cell. Accumulated lactic acid extends the period of separation of contraction elements. This is not just about ischemia. It also occurs in cases where the LV is massive, such as prediabetes, leading to indirect ischemia.

Diabetes Mellitus and prediabetes are epidemic diseases that affect the systolic and diastolic functions of the heart adversely, increasing in incidence with age. Diabetes is effective in the progressive, symptomatic progression of heart failure (HF) and increases mortality ${ }^{19}$. It is known that patients with DM may have impaired left ventricular function without coronary artery disease and hypertension. Diabetes is a pathologic cause of diastolic dysfunction, which causes LV hypertrophy independently of hypertension ${ }^{20}$. Many factors, such as myocardial fibrosis, microvascular damage, and metabolic changes, can cause these disorders ${ }^{20-26}$. DM is considered to be a stage of heart failure in the classification of ACC in 2001. It was included in the group "Patients at high risk for HF development but without the structural disorder in the myocardium." The purpose of this classification is to identify early onset individuals with a high risk of developing HF. In sixty-five percent of prediabetic patients, DM develops within six years. The rapid progression and the development of complications of diabetes even at low glycemic levels indicate the importance of early diagnosis and treatment.

In this study, our aim was; to evaluate the MPI in prediabetic patients and to test its strength as a screening test. MPI is a reproducible and easily measurable echocardiographic parameter that provides information about systolic and diastolic functions of the heart and is not affected by heart rate ${ }^{27}$. And there are prognostic values in many diseases like dilated cardiomyopathy, infiltrative cardiomyopathy, and pulmonary hypertension ${ }^{28}$. MPI can be measured by conventional methods or by tissue Doppler technique. In one study, it was mentioned that TDI could be a better alternative to prevent possible false results in conventional echocardiography when heart rate is high.

In the study of Fujita et al. When the other causes of diastolic dysfunction, aetiology were excluded, a significant difference was found between mitral $\mathrm{E} / \mathrm{A}$ ratio in prediabetic group and control group ${ }^{29}$. A similar study of 86 young, normotensive and well-glycemic control subjects found more than $40 \%$ diastolic dysfunction. ${ }^{30}$. In our study, MPI was observed to increase in addition to the decrease in mitral E / A ratio.

The higher MPI value in the prediabetic group necessitated a search for possible pathophysiological causes. Myocyte hypertrophy increased extracellular fibrous tissue, and intramyocardial microangiopathy occurs in the diabetic heart. It is also known that endotheliumdependent microvascular dysfunction, impaired relaxation, and increased passive diastolic involvement develop ${ }^{31}$. However, this mechanism is not known precisely in prediabetes. Possible pathogenesis has been mentioned in some studies which have been made in the past. Increased TGF$\beta 1$ was observed in the left ventricle due to hyperinsulinemia and hyperglycemia in prediabetic rats. Thus fibrosis developed in the myocardial tissue ${ }^{32}$. Also, in some studies, it has been shown that the level of insulin, an anabolic hormone in prediabetes, increases the production of collagen by stimulating myocytes and fibroblasts ${ }^{33}$. Increased glycation end products due to hyperglycemia accumulate in the heart and may impair diastolic function and increase left ventricular mass.

Type II Diabetes Mellitus and cardiovascular diseases are thought to have similar genetic and environmental backgrounds ${ }^{34}$. One of the common pathophysiological mechanisms of this association is insulin resistance. The basis of insulin resistance is associated with oxidative stress and inflammation. Oxidative stress and inflammation are also influential in the process of diastolic dysfunction with the effect of atherosclerosis ${ }^{35}$. In the early stages of diabetes, disorders of blood flow, and vascular permeability occur in retinas, glomerulus and vasa vasorum of peripheral nerves before structural changes become apparent ${ }^{36}$. This condition is called endothelial dysfunction. Decreased secretion of vasodilator molecules, such as nitric oxide in the vascular wall, plays an important role in the etiopathogenesis of endothelial dysfunction ${ }^{37}$. Accordingly, DM and prediabetes with hyperglycemia increase the serum CRP levels due to concomitant inflammation and atherosclerosis. 
As a result, endothelial dysfunction can develop, and diastolic dysfunction can be observed. High blood glucose levels without DM are also associated with increased hospitalization rates. In one study, it was shown that every $1 \%$ increase in $\mathrm{HbA} 1 \mathrm{c}$ levels increased the HF risk by $12 \%{ }^{38}$. Thus, hyperglycemia may be a risk factor for diastolic dysfunction.

As a result, increased MPI in prediabetic patients may give an idea of diastolic dysfunction. Early diagnosis and treatment planning by performing MPI calculations in such patients may be clinically beneficial by preventing end-organ damage. There is a need for large, randomized, and prospective studies to determine the clinical significance of this measurement.

\section{Limitations}

One of the limitations of our study was the crosssectional design and included only patients admitted to polyclinics; therefore, the results may not be relevant to the general population or other patient groups a low number of patients. Another limitation is the low number of patients in the study. Prediabetes is a process, and it is not known how the outcome will change with this process being well managed.

\section{CONCLUSION}

In prediabetic patients, we found that the MPI measured by tissue Doppler imaging was increased. MPI may be useful in demonstrating that LV diastolic functions are negatively affected in prediabetic patients. Furthermore, the most important feature of our method is that the equipment used is cheap, easy to apply, and widespread.

\section{REFERENCES}

1. M. Coutinho, H.C. Gerstein, Y. Wang, S. Yusuf. The relation ship between glucose and incident cardiovascular events: A metaregression analysis of published data from 20 studies of 95,783 individuals followed for 12.4 years Diabetes Care, 22 (1999), pp. $233-240$

2.E.B. Levitan, Y. Song, E.S. Ford, S. LiuIs nondiabetic hyperglycemia a risk factor for cardiovascular disease?: A meta-analysis of prospective studies Arch Intern Med, 164 (2004), pp. 2147-2155

3.

G. Danaei, C.M. Lawes, H.S. Vander, C.J. Murray , M. Ezzati Global and regional mortality from ischaemic heart disease and stroke attributable to higher-than-optimum blood glucose concentration: comparative risk assessment Lancet, 368 (2006), pp. 1651-1659

4. International Diabetes Federation (2017) Diabetes Atlas, $8^{\text {th }}$ edn. Available from http://www.diabetesatlas.org/. Accessed 20 May 2018

5. Amos AF, McCarty DJ, Zimmet P. The rising global burden of diabetes and its complications: estimates and projections to the year 2010. Diabet Med 1997; 14 (Suppl. 5): S1-85.

6. Michael M, Engelgau KM, Venkat N, William HH. Screening for Type 2 Diabetes. Diabetes Care 2000; 23(10):1563-80.

7. Belgi, A., Diabetic Cardiomyopathy and Heart Failure, Turkish Cardiology Seminars, October 2007, Number 5, s474

8. Nichols GA, Hillier TA, Brown JB. Progression From Newly Acquired Impaired Fasting Glucose to Type 2 Diabetes. Diabetes Care 2007; 30: 228 233.

9. The DECODE Study Group. Gender difference in all-cause and cardiovascular mortality related to hyperglycemia and newly-diagnosed diabetes Diabetologia 2003; 46: 608-617.

10. The DECODE Study Group Consequences of the new diagnostic criteria for diabetes in older men and women. DECODE Study (Diabetes Epidemiology: Collaborative Analysis of Diagnostic Criteria in Europe). Diabetes Care 1999; 22: 1667- 1671.

11. Chiasson JL et al. Acarbose treatment and the risk of cardiovascular disease and hypertension in patients with impaired glucose tolerance: the STOP-NIDDM trial. JAMA 2003; 290: 486-494.

12. Tei C, Ling LH, Hodge DO, Bailey KR, Oh JK, Rodeheffer RJ et al. (1995). A new index of combined systolic and diastolic myocardial performance: a simple and reproducible measure of cardiac function - a study in normals and dilated cardiomyopathy. J Cardiol 26: 357-368

13. Tei C, Dujardin KS, Hodge DO, Kyle RA, Tajik AJ, Seward JB (1996) Doppler index combining systolic and diastolic myocardial performance: clinical value in cardiac amyloidosis. Am Coll Cardiol 28: 658-664

14. Bruch C, Schmermund A, Marin D, Katz M, Bartel T, Schaar J, Erbel R (2000) Tei-index in patients with mild-to-moderate congestive heart 
failure. Eur Heart J 21(22):888-895

15. Tavil Y, Ozturk MA, Sen N, Kaya MG, Hizal F, Poyraz F, Turfan M, Onder M, Gurer MA, Cengel A. The assessment of cardiac functions by tissue Doppler-derived myocardial performance index in patients with Behcet's disease. Clin Rheumatol. 2008 Mar; 27(3):309-314. Epub 2007 Aug 3.

16. Mishra RK, Kizer JR, Palmieri V, Roman MJ, Galloway JM., Fabsitz RR, Lee ET, Utility Of The Myocardial Performance Index İ A Population With High Prevalences Of Obesity, Diabetes, And Hypertension: The Strong Heart Study Echocardiography: A Jrnl. Of $\mathrm{CV}$ Ultrasound \& Allied Tech. Vol. 24, No. 4, 2007

17. Shetty P, Kumanyika S, Ko GT. Waist circumference and waist-hip ratio: report of a World Health Organization expert consultation, Geneva, 8-11 December 2008.

18. Schiller NB, Shah PM, Crawford M, et al. Recommmadation of quantitation of the left ventricle by two-dimensional echocardiography. American Society of Echocardiography Committee on Standards, Subcommittee on TwoDimensional Echocardiogram. J Am Soc Echocardiogr 1989; 2:358-367.

19. Wild S, Roglic G, Gren A, Sicree R, King H. Global prevalence of diabetes: estimates for the year 2000 and Project for 2030. Diabetes Care 2004; 27(5):1047-53

20. Rodrigues B, Cam MC, McNeill JH. Metabolic disturbances in diabetic cardiomyopathy. Mol Cell Biol Biochem. $1998 ; 180,53-57$

21. Airaksinen KEJ, Salmela PI, Linnaluoto MK, Ikaheimo MJ, Ahola K, Ryhanen LJ: Diminished arterial elasticity in diabetes: association with şu o recent advanced glycosylation end products in collagen. Cardiovasc Res 27.942-945, 1993

22. Depre C, Young ME, Ying J, et al. Streptozotocin-induced changes in cardiac gene expression in the absence of severe contractile dysfunction. J Mol Cell Cardiol. 2000; 32.985996.

23. Heinecke JW. Oxidative stress: new approaches to diagnosis and prognosis in atherosclerosis. Am J Cardiol 2003;91(Suppl):12$6 \mathrm{~A}$.

24. Ceriello A. Coagulation activation in diabetes mellitus: the role of hyperglycaemia and therapeutic prospects. Diabetologia 1993;36:
$1119-25$.

25. Ceriello A, Falleti E, Motz E, et al. Hyperglycemia-induced circulating ICAM-1 increase in diabetes mellitus: the possible role of oxidative stress. Horm Metab Res 1998; 30: 1469.

26. Brownlee M. Biochemistry and molecular cell biology of diabetic complications. Nature 2001; 414: 813-20.

27. Rudski LG, Lai WW, Afilalo J, et al.Guidelines fort he echocardiographic assessment of the right heart in adults:a report from the American Society of Echocardiography endorsed by the European Association of Echocardiography, a registered branch of the European Society of Cardiology,and the Canadian of Echocardiography,J Am Soc Echocardigr.2010;23(7):685-713.

28. Özer $N$. Kalp yetmezliğinin semptom ve bulguları. Editörler Kozan Ö. Zoghi M. A"e dan Zee ye Kalp Yetersizliği. Güneş Tip Kitabevi 2010; 7:89-94.

29. M. Fujita et al. / International Journal of Cardiology 118 (2007) 76-80

30. Di Bonito $\mathrm{P}$, Cuomo $\mathrm{S}$, Moio $\mathrm{N}$, et al. Diastolic dysfunction in patients with non-insulindependent diabetes mellitus of short duration. Diabet Med 1996; 13: 321-4.

31. Kaftan A. H. Kalp Yetersizliği Etiyolojisi. Editörler Kozan Ö. Zoghi M. Ae dan Z $Z^{\text {ee }}$ ye Kalp Yetersizliği. Güneş Tıp Kitabevi 2010; 5: 49-56

32. Mizushige $\mathrm{K}$, Yao L, Noma $\mathrm{T}$, et al. Alteration in left ventricular diastolic filling and accumulation of myocardial collagen at insulin resistant prediabetic stage of a type II diabetic rat model. Circulation 2000; 101: 899- 907.

33. Goldstein RH, Poliks CF, Pilch PF, Smith BD, Fine A. Stimulation of collagen formation by insulin and insulin-like growth factor I in cultures of human lung fibroblasts. Endocrinology 1989; 124: $964-70$.

34. Sterdlow AJ, Jones ME. Mortality during 25 years of follow-up of a cohort with diabetes, Int $\mathbf{J}$ Epidemiol 1999;25(6):1250-61.

35. Hu FB, Stampfer MJ, Haffner SM, et al, Elevated risk of cardiovascular disease prior to clinical diagnosis of type 2 diabetes, Diabetes care 2002;25(7):1129-34.

36. Kihara N, Sasson S, Feener EP, et al.Differential regulation of glucose transport and 
transporters by glucose in vascular endothelial and smooth muscle cells.Diabetes 1993;42(1):8090.

37. Brownlee M, Friedman E, Vinik Al, Nesto RW, Boultın AJM. Complications of Diabetes Mellitus. Ed: K. Larsen, Kronenberg, Melmed, Polonsky, Williams Textbook of Endocrinology.pp.1510-1583, Saunders, Philadelphia, USA, 2003

38. I Stratton, A. Alder, H. Neil, D. Natthews, S Manley, C. Cull and on behalf of the UKPDS Study Group, UKPDS 35: Association of glycemia with macrovascular and microvascular complications of type 2 diabetes (UKPDS 35): a prospective observational study. BMJ 2000: 321; 405-12. 